\title{
Tanah Papua, Asia-Pacific news blind spots and citizen media From the 'Act of Free Choice' betrayal to a social media revolution
}

\begin{abstract}
For five decades Tanah Papua, or the West Papua half of the island of New Guinea on the intersection of Asia and the Pacific, has been a critical issue for the region with a majority of the Melanesian population supporting self-determination, and ultimately independence. While being prepared for eventual post-war independence by the Dutch colonial authorities, Indonesian paratroopers and marines invaded the territory in 1962 in an ill-fated military expedition dubbed Operation Trikora ('People's Triple Command'). However, this eventually led to the so-called Act of Free Choice in 1969 under the auspices of the United Nations in a sham referendum dubbed by critics as an 'Act of No Choice' which has been disputed ever since as a legal basis for Indonesian colonialism. A low-level insurgency waged by the OPM (Free West Papua Movement) has also continued and Jakarta maintains its control through the politics of oppression and internal migration. For more than five decades, the legacy media in New Zealand have largely ignored this issue on their doorstep, preferring to give attention to Fiji and a so-called coup culture instead. In the past five years, social media have contributed to a dramatic upsurge of global awareness about West Papua but still the New Zealand legacy media have failed to take heed. This article also briefly introduces other Asia-Pacific political issues_-such as Kanaky, Timor-Leste, Papua New Guinean university student unrest, the militarisation of the Mariana Islands and the Pacific's Nuclear Zero lawsuit against the nine nuclear powers - ignored by a New Zealand media that has no serious tradition of independent foreign correspondence.
\end{abstract}

Keywords: citizen media, foreign correspondence, independence, Indonesia, insurgency, media 'blind spots', news media, New Zealand, Papua, postcolonialism, self-determination, social media, West Papua

\section{DAVID ROBIE}

Pacific Media Centre, AUT, Auckland

\section{Introduction}

HIS ESSAY begins with a question? Who has ever heard of Tanah Papua? Or for that matter Irian Barat? How about Papua Barat? An affirmative response comes more rapidly when referring to West Papua, but with a 


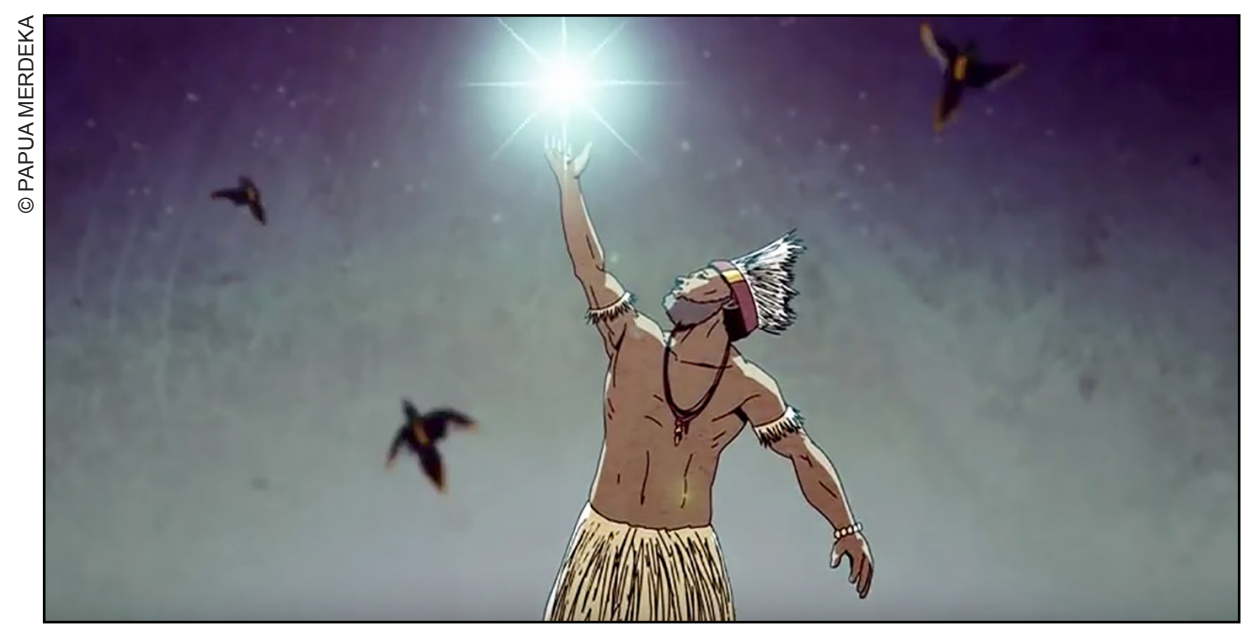

Figure 1: The 'Morning Star'-the iconic symbol of West Papuan independence.

rather fuzzy concept perhaps? The Dutch-colonised half of the western Pacific island of New Guinea was known as Papua and Irian Jaya. But after a sham plebiscite in 1969 following a paratrooper-led invasion in the region eight years earlier, the half island became largely known by those who supported self-determination and eventual independence as 'West Papua'.

The colonising Indonesians called the province Irian Jaya in 1973- jaya' meaning victorious, in reference to the 'liberation' of the territory from Dutch colonial rule (King, 2004). However, in 2003, Jakarta split the West Papuan region into two provinces - Papua, the largest and more populous province around the capital of Jayapura which shares the border with Papua New Guinea, and Papua Barat with a combined population of 3,612,854 people, two thirds of them Papuan, according to official census figures from the Badan Pusat Statistik (BPS) office (Elmslie, 2017). The indigenous people of West Papua, as this article refers to the region (both provinces) from now on, comprise some 250 diverse tribes, all with unique languages and cultures. They are largely Christian, although there are significant Muslim minorities around Manokwari, Fakfak and Sorong.

In the past half century, Indonesia has imposed on the Papuan people a massive social engineering project that has involved transmigration of tens of thousands of largely Muslim Javanese into the region, which from 2010 onwards has been rapidly turning the Indigenous people towards a minority (Elmslie, 2013; Webb-Gannon, 2015). In a more recent paper revisiting West Papuan demographics, West Papua Project convenor Jim Elmslie has indicated that while the Papuan people 'continue to decline, this process varies widely between different regencies' $(2017, \mathrm{p} .1)$. Although transmigration is no longer the official policy, the transformation that it unleashed has happened largely hidden from the Australian and New Zealand news media, even though this has been arguably the most devastating Pacific political 
and social story of our times (Papua Merdeka, 2015 [Video]). For a region that is little known in New Zealand, least of all among media news editors or international news directors, many things have been happening in recent times that ought to be raising newsroom antennae.

Surprisingly not so, in spite of two New Zealand media initiatives in 2015 that ought to have stirred curiosity among local media organisations. One was the first visit by a New Zealand television crew in a half century to West Papua-by Māori Television's Native Affairs current affairs programme - and the other by Radio New Zealand International. One of the missions (Māori Television) was supported by the Asia New Zealand Foundation, which in itself is salutary because the foundation has found this to be a worthy cause to endorse in spite of the general lack of local media interest and high political sensitivity over the issue.

For more than five decades, the legacy media in New Zealand have largely ignored this issue on their doorstep, preferring to give attention to Fiji and a socalled coup culture instead. In the past five years, social media have contributed to a dramatic upsurge of global awareness about West Papua but still the New Zealand legacy media have failed to take heed. This article also briefly includes other Asia-Pacific political issues - such as Kanaky, Timor-Leste, Papua New Guinean university student unrest, the militarisation of the Mariana Islands and

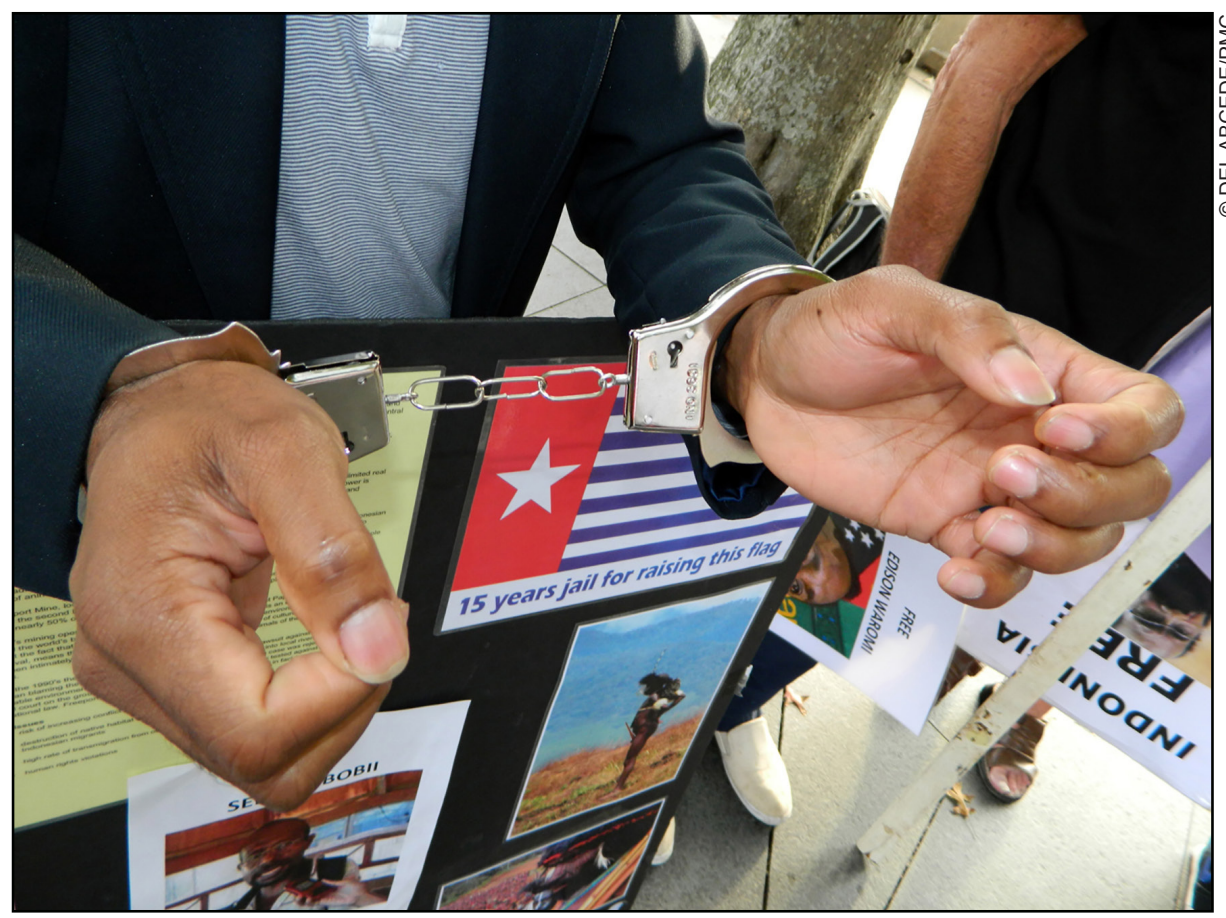

Figure 2: 'West Papua in chains': displaying the Morning Star flag risks 15 years in jail. An Auckland solidarity demonstration. 
the Pacific's Nuclear Zero lawsuit against the nine nuclear powers-ignored by a New Zealand media that has no serious tradition of independent foreign correspondence.

\section{'Pre-emptive' mass arrests in West Papua}

On the historically significant anniversary date of 1 May 2016, global social media ran hot with updates on massive protests against the rule from Jakarta and more than 2000 arrests were made - 4198, according to one comprehensively documented report (MacLeod, et al., 2016, p. 19; Wenda, 2016a; Mass arrests reported, 2016). These protests took place 53 years after a United Nations Temporary Executive Authority (UNTEA) had handed power over to the former Dutch colony in West New Guinea to Jakarta with a mandate to rule until such time as the Papuan people decided on their future in a free vote. Even then a future referendum had been envisaged. Instead, the sham 'Act of Free Choice' was orchestrated in 1969 with a handpicked group of 1050 men and women (out of a population at the time of more than 800,000 people) who were publicly coerced into choosing to be incorporated into the Republic of Indonesia (MacLeod, et al. 2016, p. 11).

Such critical dates as this - and on 1 December 1961, when colonial Ordinances came into force recognising Papuan 'independence' with a Dutch blessing, a Manifesto, a national flag (the strikingly photogenic Morning Star, which is banned in Indonesia), and a national anthem ('Oh My Land Papua') — have been observed every year since an Indonesian paratrooper invasion in January 1962.

However, in May 2016 a wave of 'pre-emptive' mass arrests was made, rounding up hundreds of activists, and this demonstrated the compelling popular support among Papuans for self-determination and how this has been steadily growing stronger over the half century, partly fuelled by recent social media campaigns by solidarity groups around the globe (Titifanue et al., 2017a, 2017b, pp. 134-5). A lawyer advocate for the Jakarta Legal Aid Institute, Veronica Koman (2016), wrote in The Jakarta Post:

In early May [2016], 2109 Papuan independence protesters were arrested by police - and that number is more than double the 1025 who were pressganged into legitimising Indonesia's rule of Papua through the 1969 'Act of Free Choice'.

Despite our Indonesian Embassy in the United Kingdom denying in The Guardian that the arrests took place, the Jakarta Legal Aid Institute documented them all, and holds the names of every one of the 2109 demonstrators ...

This is the historical reality that underpins today's grievances about state violence, environmental degradation and suppression of free speech in Papua. (Koman, 2016) 
Until these grievances are addressed, argues Koman, the protests by Papuans will continue and the numbers will continue to add up. She noted that, according to her agency's records, as at mid-May 2016, 'the figure stands at 2282 peaceful demonstrators detained by police'.

Also happening that eventful month was an extraordinary meeting of more than 100 parliamentarians, politicians, civil rights lawyers and activists from some 23 countries who gathered in London to adopt the Westminster Declaration, which branded the 1969 vote as a 'gross violation of the right to self-determination'. It also called for an internationally supervised referendum in Papua.

\section{Danger zone for journalists}

As I have commented elsewhere (see Perrottet \& Robie, 2011; Robie, 2012, 2014), the reportage of both East Timor/Timor-Leste and West Papua over several decades has been, and still is, a 'highly risky business, as evinced by the killing of six Australian-based journalists - the so-called Balibó Five, and then Roger East who went to East Timor to investigate their deaths - during the invasion by Indonesia in 1975' (immortalised in the 2009 Robert Connolly feature film Balibó, www.balibo.com [Video]) (Robie, 2013; Shackleton, 1975).

In 2011, a former postgraduate student with the Pacific Media Centre, Alex Perrottet, now working as a journalist with Radio NZ International (RNZI), and I prepared the first media freedom report on the Asia Pacific region. We concluded at the time in our 'Pacific Media Freedom 2011: A status report' for both Pacific Journalism Review and as a Pacific Journalism Monograph No. 1:

By far the most serious case of media freedom violations in the Pacific is in Indonesia-ruled West Papua (now split into two provinces in a 'divideand-rule' tactic by the authorities in Jakarta). Amid the backdrop of renewed unrest and mass rallies demanding merdeka, or freedom, with two bloody ambushes in Abepura on the outskirts of the capital Jayapura in early August 2011, sustained repression has also hit the news media and journalists. In the past year, there have been two killings of journalists, five abductions, or attempted abductions, 18 assaults (including repeated assaults against some journalists), censorship by both the civil and military authorities, and two police arrests (but no charges). (Perrottet \& Robie, 2011, p. 148)

To put this into context, the continual harassment and attacks on journalists, along with others in the Papuan population, we need to return to this bloody tragedy back at the border township of Balibó in 1975. As film director Robert Connolly has noted, that because these murders of the Balibó Five were carried out with impunity - neither the Australian nor the New Zealand governments (a Kiwi journalist, Greg Cunningham was among the victims), seriously protested-this failure directly led to the execution of a sixth journalist, Roger East, 
a veteran Australian who had stayed in Dili to report on the Indonesian invasion. His fledgling East Timor news agency was trashed on 7 December 1975 and he was dragged out and shot at the main wharf of the city (Coroner finds Balibo Five deliberately killed, 2007; Cronau, n.d.; Balibó, 2009 [Video]).

These events were a game-changer. While journalists had previously died in conflict and war zones, the Balibó massacre and subsequent execution of Roger East were believed to be the first time journalists had been killed because they were journalists. There are close parallels between Timor-Leste-chronicled admirably by Maire Leadbeater (2006) in her Negligent Neighbour - and a forthcoming book on West Papua (Leadbeater, 2018), and the terrible brunt borne by journalists as well as ordinary West Papuan citizens.

In July 2014, Green Party MP Catherine Delahunty surprised the New Zealand Parliament with an untabled motion calling on Indonesian President Joko 'Jokowi' Widodo to 'commit to genuine media freedom' in West Papua, 'including the right of local and international journalists to report there without risk of imprisonment or harassment'. Her motion won unanimous cross-party support in the vote (Motions-human rights, 2014; Robie, 2014).

This apparent turning of a new leaf by Widodo led to the first television crew from New Zealand travelling to West Papua in half a century in August 2015Māori Television's Native Affairs reporter Adrian Stevanon with Pacific Media Centre researcher Karen Abplanalp (Abplanalp, 2015; Native Affairs-Inside West Papua, 2015; Native Affairs sends first NZ TV crew, 2015)—followed by a Radio New Zealand International team, Johnny Blades and Koroi Hawkins, in October (Blades, 2015, 2016).

While this shed some light on developments in West Papua for a New Zealand audience, Stevanon managed an intriguing report on an aid-funded kumara production project in the Highlands, these were still stage-managed media visits in many respects. A video story produced by one of our student journalists on the postgraduate Asia Pacific Journalism course, Media 'freedom 'in West Papua exposed (Purdie, 2014 [Video]) gave the lie to claims from Jakarta that Indonesia had adopted a more 'relaxed' policy towards foreign journalists trying to visit West Papua.

A disappointing outcome from the two visits to West Papua officially for the first time by New Zealand journalists in 2015 is that so far these initiatives have not encouraged other media in New Zealand, especially print, to take up the challenge. An Australian investigative journalist of SBS Dateline, Mark Davis, has twice visited West Papua as an underground, illegal journalist. He was thus hardly Jakarta's favoured journalist. Yet in May 2014 he also had the opportunity for rare access to the secretive region to find out what is really happening in the struggle over self-determination with Indonesia. The title of his half-hour television report raised the question West Papua's New Dawn? Hardly at all. A 
major question for journalists is just how much do we offer a figleaf to Jakarta by cooperating with these heavily 'minded' see-no-evil, hear-no-evil visits to the region (Davis, 2014 [Video]). The Indonesian authorities go to extraordinary lengths to gag and silence dissent and discourse about West Papua throughout the republic. This was demonstrated yet again during the four-day UNESCO World Press Freedom Day conference hosted by Indonesia in Jakarta on 1-4 May 2017 when West Papua was marginalised from the programme (Sapiie, 2017). I was invited as one of the keynote speakers at a parallel 'Free West Papua Media' seminar on May 2 attended by journalists, media workers and human rights lawyers (Robie, 2017a, 2017b). It is essential for New Zealand and global journalists to continue to push the boundaries with West Papua, through both 'official' and 'unofficial' visits to both expose the oppression and to report development issues in the twin provinces.

\section{Fact-finding missions record 'intimidation and brutality'}

Early in 2016, a Catholic Justice and Peace Commission fact-finding mission from Australia visited West Papua in lieu of the Pacific Islands Forum summit's initiative which had been decided at the Port Moresby summit in September 2015 but blocked by Indonesian authorities. The mission produced a critical report in May 2016 that called for urgent action to support Papuans who were 'living with unrelenting intimidation and brutality' (Catholic Justice \& Peace Commission, 2016). The report said:

The situation in West Papua is fast approaching a tipping point. In less than five years, the position of Papuans in their own land will be worse than precarious. They are already experiencing a demographic tidal wave. Ruthless Indonesian political, economic, social and cultural domination threatens to engulf the proud people who have inhabited the land they call Tanah Papua for thousands of years. (Catholic Justice \& Peace Commission, p. 2)

The report was equally damning on issues of freedom of expression and the media, concluding:

Despite an announcement in May 2015 by President Widodo that journalists would have free access to West Papua, media access is still restricted. There is no freedom of expression. Almost 40 political prisoners are currently in jail [written before the 2000 plus arrests on May 1/2 this year and then a further 1000 plus arrests on June 15], customary land rights are not protected and there is no systemic policy of affirmative action. West Papuan human rights are also not protected. Throughout 2015, the Indonesian security forces have targeted young people in particular, all of whom have been unarmed. (Catholic Justice \& Peace Commission p. 11) 
The implications for freedom of expression and the press, and safety of journalists, in West Papua is obscured by various global media freedom reports which effectively hide the region (the two provinces of Papua and West Papua) in the body text of their dossiers. According to Reporters Sans Frontières' 2016 World Press Freedom Index, Indonesia was 130th out of 180 nations surveyed and the report noted Widodo's presidency continued to be 'marked by serious media freedom violations, including lack of access to West Papua, a media freedom black hole'. The report continued:

Journalists and fixers working there are liable to be arrested. The problem is compounded by Indonesia's visa law, which discriminates against foreign journalists. At the same time, many poorly paid journalists accept bribes in return for positive coverage. (RSF, 2016a)

In Freedom House's 2015 World Press Freedom report on Indonesia, the West Papuan situation also faced severe criticism:

Media coverage of the sensitive issue of Papuan separatism continued to draw special scrutiny and restrictions from the government ... Before taking office, President Widodo pledged that he would allow international journalists and organisations access to Papua and West Papua; however, this did not happen by year's end. The Indonesian authorities effectively block foreign media from reporting in the two provinces by restricting access to those with official government approval, which is rarely granted. The few journalists who do gain permission are closely monitored by government agents, who control their movements and access to local residents. (Freedom House, 2015)

I challenge the reference in this statement to the word 'separatist', which is routinely used by Indonesian authorities to brand their Papuan opponents in a negative light and to help justify their repression. In this context, I find this term 'separatist' obscene and yet it is regularly repeated by news agencies and New Zealand media, which should have a better knowledge of our region in the rare times that West Papua even makes the news in this country. Indigenous people cannot be separatists from their own traditional and customary lands. They have a right to self-determination and to express this aspiration.

According to Human Rights Watch, 'the [Indonesian] military has also financed and trained journalists and bloggers, citing alleged foreign interference in the region, including by the US government' (cited by Robie, 2016a, p. 9). Following the mass arrests in early May 2016, RSF issued a communique calling on the Indonesian government to 'stop violating the rights of journalists in West Papua'. It particularly condemned the Jayapura police for preventing reporters from covering a peaceful demonstration in support of the United Liberation 
Movement for West Papua (ULMWP) on May 2-ironically, the eve of World Press Freedom Day. The communique said:

Ardi Bayage, a journalist working for the Suarapapua.com news website, was arrested at the same time as other protesters although he showed his press card to the police. The authorities, who accused him of lying, broke his mobile phone and took him to the mobile brigade's headquarters, where he was held for several hours. (RSF, 2016b)

Benjamin Ismail, then head of RSF's Asia-Pacific desk, said: 'We condemn this violence and censorship of local journalists whose coverage of these demonstrations was in the public interest' (RSF, 2016b). Ismail also cited the ban on France 24 journalist Cyril Payen, prohibiting him from future visits after he had filed an in-depth television report on West Papua, and a violent attack by police on local Tabloid Jubi journalist Abeth You on 8 October 2015 while covering a demonstration in Jayapura by a group called Solidarity for Victims of Human Rights Violations in Papua (RSF, 2016b).

Police also arrested and questioned two fixers working for a French journalist, according to Ismail. This highlights the greater risks faced by local people who collaborate with foreign journalists to provide them with information.

\section{Indonesian diplomacy campaign}

While such protests were being aired in international news media, Indonesia had embarked on a blatant diplomacy campaign around the region, especially focusing on the two principal Melanesian Spearhead Group member states and largest economies, Fiji and Papua New Guinea. The MSG is an increasingly important sub-regional group, both part of the Pacific Islands Forum and in some respects a rival to the PIF. It also has status at the United Nations (MacLeod et al., 2016).

Aid largesse was widely distributed and the Indonesian military event went so far as to join the 'adopt-a-school' programme to help repair the devastation in Fiji left by Cyclone Winston. Local NGO groups protested and opposition MPs questioned this development after Indonesian soldiers were seen as part of the reconstruction programme at Queen Victoria School in Suva. One hundred Indonesian soldiers were deployed in Fiji at the time of preparing this article (Sauvakacolo, 2016).

Opposition MP Roko Tupou Draunidalo asked in the Fiji Parliament why the construction contract was given to the Indonesian government which stood accused of genocide in West Papua:

How much are these 20 pieces of silver help to seal your government's mouth on the issue of genocide in West Papua and why has the government 
not sought assistance from other governments like the British government if it required, or a Commonwealth country to build a school named after Queen Victoria? (quoted in Swami, 2016)

The answer, incidentally, from Education Minister Dr Mahendra Reddy was that the question was totally irrelevant. Just three days later Roko Tupou was suspended from Parliament for the rest of the parliamentary term due to end in 2018. An extraordinary gag.

Publicly, Roko Tupou was suspended by a vote of 28 votes to 16 on the recommendation of the Parliamentary Privileges Committee (comprised of four FijiFirst government members) following a cross-floor shouting match when she was accused of calling Education Minister Reddy 'a fool'. In her defence, she claimed that this was in response to a statement by Dr Reddy that implied worse of the Opposition: 'Calling us dumb natives?' (Fiji MP Draunidalo suspended, 2016).

My suspicion is that the real reason for her suspension was to shut down her embarrassing questions about Indonesia and its relationship with the Fiji government. The insults were in effect a smokescreen. Draunidalo made a formal apology on June 10.

Writing in Asia Pacific Report, Tarcisius Tara Kabutaulaka of the University of Hawai'i at Manoa, severely criticised the Indonesian diplomacy efforts in the Pacific, particularly in Melanesia, warning that Pacific nations should not be bullied, adding that: 'Indonesia is not Melanesia'. Replying to an Indonesian statement condemning Solomon Islands Prime Minister Manasseh Sogavare, Tara wrote:

Indonesia has persistently committed human rights violations, including atrocities, against Melanesians in West Papua for over 50 years. That is not a myth. It is the truth. It has been verified and documented by international human rights organisations such as Amnesty International and other independent bodies.

For Indonesia to say that it is 'long committed to address human rights issues,' is misleading and an attempt to deflect attention from realities on the ground in West Papua. (Kabutaulaka, 2016)

The most recent evidence of the Indonesian diplomatic offensive in the region was at the 48th Pacific Islands Forum Leaders Meeting in Apia, Samoa, when Jakarta's Ambassador to New Zealand, Samoa and Tonga, Tantowi Yahya, and a Papuan attached to Indonesia's Ministry of Foreign Affairs, Franz Albert Joku 'rubbished' a prominent protest by Pacific trade unionists and human rights activists over violations in West Papua. Yahya added: 'The Pacific community should stick to the main agenda of the conference, which is the Blue Pacific.' (Feagaimaali'i-Luamanu, 2017). 


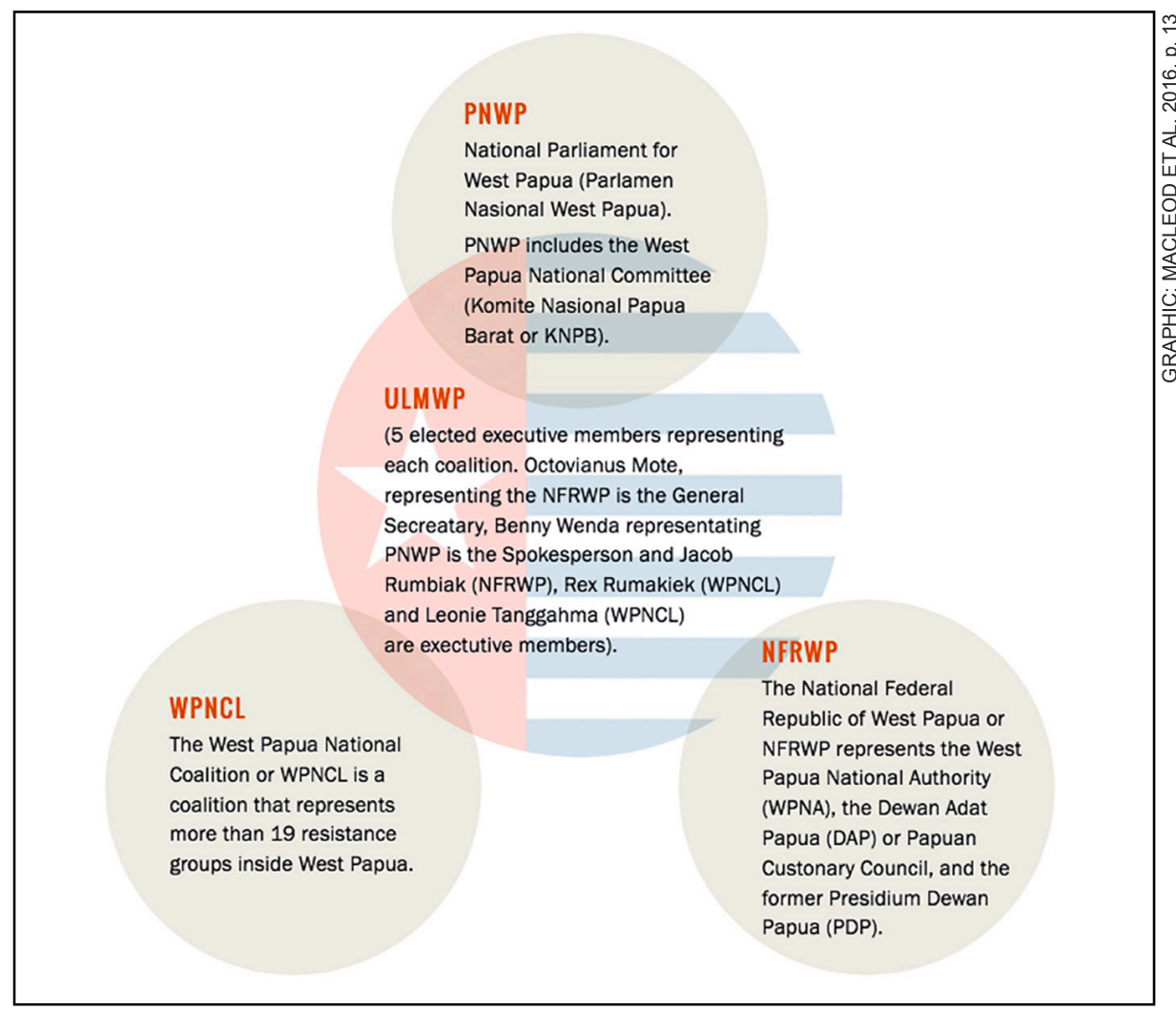

Figure 3: Power relationships: The United Liberation Movement for West Papua.

\section{Peaceful protests crushed}

On 15 June 2016, thousands of West Papuan people rallied in the streets of towns across the nation to call for freedom and for their fundamental right to self-determination to be exercised. They showed their full support for the United Liberation Movement for West Papua's (ULMWP) full membership of the Melanesian Spearhead Group (MSG). The Papuan people also rallied to show their support for the proposed Pacific Islands Forum Human Rights FactFinding Mission to West Papua, and a rejection of Indonesia's 'false attempts' at establishing an Indonesian-led Fact-Finding Mission. The Papuan people gathered peacefully in a massive display of solidarity to show their true aspirations. Exiled West Papuan leader Benny Wenda stated with optimism:

I hope that the world will look and see these demonstrations as evidence that we, the people of West Papua, continue to risk our lives by simply calling for our fundamental right to self-determination. (Wenda, 2016a)

Benny Wenda's hopes were shortlived. Instead, the Indonesian police were determined to use brute force to crush the peaceful protests and more than 1000 
people were arrested, mostly in Jayapura, and some of the detainees were badly beaten (Wenda, 2016b).

Such mass arrests and brutality are becoming increasingly common in West Papua and it is estimated that in the last two months, nearly 3000 West Papuan people have been arrested by the Indonesian authorities simply for peacefully demonstrating and calling for our fundamental right of self-determination to be exercised.

My people cannot be silent while our fundamental human rights continue to be published, violated and denied to us by this brutal occupying colonial power. (Wenda, 2016b)

Wenda declared that a Pacific Islands Forum Fact-Finding mission was desperately needed in West Papua to help 'uncover, document and expose' these ongoing human rights violations. He argued that the Indonesian government was trying to claim that there were only 11 human rights abuses that needed to be investigated in 'occupied West Papua'. Wenda has attempted to correct public misinformation about West Papua (Wenda, 2016c).

The Indonesians have also attempted to argue unsuccessfully that Indonesia has five Melanesian provinces, not just the two Papuan provinces on the island of New Guinea (Robie, 2015). After the last Melanesian Spearhead Group Leaders Summit in Honiara in what was generally portrayed as a victory for West Papua by granting observer status to the ULMWP, I took a different view and described the summit as 'the most shameful' for solidarity since the organisation had been founded two decades earlier. I wrote on my blog Café Pacific:

[The MSG] had the opportunity to take a fully principled stand on behalf of the West Papuan people, brutally oppressed by Indonesia after an arguably 'illegal' occupation for more than a half century ...

In the end, the MSG failed the test with a betrayal of the people of West Papua by the two largest members [Fiji and Papua New Guinea]. Although ultimately it is a decision by consensus. Instead, the MSG granted Indonesia a 'promotion' to associate member status - to an Asian country, not even Melanesian? (Robie, 2015)

\section{News media 'blind spots'}

In my abstract for this article, I wrote about news media blind spots in New Zealand. This was originally going to be a key part of this article. But the West Papuan 'black spot' issue became so urgent that most of the article has referred primarily to West Papua. Nevertheless, I will refer here briefly to some other issues that have been virtually ignored by the legacy media in this country. Why is this so? Primarily because we have no genuine tradition of foreign correspondents and foreign editors in New Zealand, so the specialist and back- 
ground knowledge required to make informed judgment calls is seriously lacking. There is also a reluctance to deploy resources to international reporting, in contrast to the leading newspapers in Australia such as The Age, The Australian and The Sydney Morning Herald.

1980s: The issue of Kanak independence in the French Pacific territory of New Caledonia, New Zealand's closest Pacific neighbour and a major upheaval during the 1980s over independence, threatened to spill over into a civil war. At one stage, arguably the finest contemporary Kanak political leader, the charismatic Jean-Marie Tjibaou and his deputy Yeiweni Yeiweni were assassinated by dissidents within the main FLNKS party. A referendum on possible independence from France is due in 2018 as the Matîgnon Accord expires (Robie, 1989, 2014).

2015/16: In the Commonwealth of the Northern Marianas, eight community groups have been preparing a lawsuit against the US Department of the Navy and the US Fish and Wildlife Service for failure to comply with the Endangered Species Act (ESA) (Mariana Islands community groups, 2016). Notice of this lawsuit was received by the US Department of Defense, the US Department of the Interior, the Secretary of the Navy at the Pentagon and the Director of US Fish and Wildlife Service earlier on 25 February 2016 (Frain, 2016, 2017).

2013/16: On 24 April 2014, the Republic of the Marshall Islands (RMI) filed applications in the International Court of Justice (ICJ) to hold the nine nucleararmed states accountable for violations of international law over their nuclear disarmament obligations under the 1968 Nuclear Non-Proliferation Treaty (NPT) and customary international law (Lawyers Committee, n.d.; The Marshall Islands' Nuclear Zero Cases, 2016). The nine states possessing nuclear arsenals are the United States, United Kingdom, France, Russia, China, India, Pakistan, North Korea, and Israel. However, the ICJ rejected the lawsuit on October 6, saying the court did not have jurisdiction because there was no evidence of a legal dispute that it could adjudicate (Simons, 2016; Summary of Judgment, 2016).

The cases were founded on the unanimous conclusion of the ICJ in a 1996 advisory opinion, that there "exists an obligation to pursue in good faith and bring to a conclusion negotiations leadings to nuclear disarmament in all its aspects under strict and effective international control'. Dubbed as Nuclear Zero by the legal advisers that have been helping the RMI in this case, this intriguing saga has been given very little coverage in NZ media.

8 June 2016: The Papua New Guinea police fired upon peacefully protesting students at the University of Papua New Guinea with tear gas and live rounds. While the police claimed they were warning shots, there were incorrect initial reports of four deaths and dozens wounded, but these estimates were later downgraded to 23 wounded, four critically who later recovered. The incident followed five weeks of rolling protests and boycotts at the country's four main universities with demands that Prime Minister Peter O’Neill step down and face 
an investigation of corruption allegations. (O’Neill was subsequently narrowly re-elected in a closely fought general election in July 2017). New Zealand media virtually ignored these developments (Matasororo, 2016; Robie, 2016c; Somare condemns police, 2016).

\section{Digital revolution}

The digital revolution is one of the major contributing factors in even getting this far with global awareness over West Papua and there is optimism that the region will ultimately become full members of the Melanesian Spearhead Group, sooner rather than later. Social media over the past five years has provided an unprecedented impetus to the self-determination and independence struggle with West Papuans challenging the authoritarian ruthlessness of the Indonesian security forces with a constant stream of videos showing torture and mass arrests in response to peaceful protest. The independent West Papua Media alerts agency has played a key role in this social media strategy and there has 'been a rise of the nonviolent movement and ordinary people's support for freedom can be seen by the rise in mass mobilisations' (MacLeod et al., p. 19). According to Jason Titifanue and colleagues at the University of the South Pacific (2017) in a paper on social networking as a political tool in the Pacific, while there is no general consensus on the effectiveness of social media in activism, their findings indicate it has been a 'valuable tool for facilitating and organising activism' in the Free West Papua campaign. They argue that 'with journalists being restricted from entering West Papua, social media have become the only option for West Papuans to share their plight with the rest of the world' (Titifanue et al., p. 275). Harsh atrocities depicted through social media have stirred offline political activism through protests and marches. This has in turn played out with influence on Pacific governments.

Australian digital humanities researcher Camellia Webb-Gannon (2015) has written in her doctoral thesis about 'transformative democratisation, in essence purposeful action' at the grassroots level and international solidarity for West Papua that may ultimately lead to a shift in policy by the Australian and New Zealand governments and in turn an awakening of the New Zealand media to the desperate West Papuan issue. She noted:

This is expressed in a burgeoning genre of West Papua independence music being created by West Papuans and their Melanesian and Australian supporters and distributed digitally via YouTube, Soundcloud, iTunes, Bluetooth and SD cards through ever expanding digital networks. While evidently the digital revolution has not impacted on all populations equally, it has had the effect of spreading music, foundational to Melanesian cosmology and the life force of West Papua's independence movement widely, and lifting the regional profile of the West Papuan struggle. (Webb-Gannon, 2015) 
Jason MacLeod is another Australian, educator, organiser and researcher, who did his own doctoral research on how contemporary Papuans struggling for change 'dream, plan and act in pursuit of self-determination and decolonisation'. In his 2015 book Merdeka and the Morning Star, and a later journal article in Pacific Journalism Review, he offers a critical update demonstrating how the armed struggle has given way to an extraordinary process of 'civil resistance' and social media mobilisation (MacLeod, 2015, p. ix; 2016).

Although many Papuans feel intense pride for the guerrillas in the mountains and jungles who continue to wage armed struggle, few Papuans are willing to risk their lives committing to a strategy of guerrilla war that has little prospect of success ... Nonviolent action is also more numerous and more regular than politically motivated violent action.

Barely a week, or even a day goes by without some kind of nonviolent protest in the cities and towns of West Papua, over violations of basic rights or demands 'full freedom'. (MacLeod, 2015, p. 14)

Indonesia's top 15 'enemies of the state' in West Papua, according to journalist Alan Nairn (2010), who exposed a list of 'civilian dissidents' from leaked Kopassus military papers, are community leaders, church leaders, students, members of parliament and leaders of the Papuan Customary Council. As a postscript to his book, MacLeod (2015, p. 243; MacLeod, et al., 2016) writes of the extraordinary effort from people inside West Papua campaigning for the ULMWP to gain membership of the MSG. He personally witnessed the unwrapping of five $27 \mathrm{~kg}$ hessian-wrapped packages in Honiara last June. Each parcel contained two massively thick A4-sized books.

In an age of easy Facebook likes, and the growing importance of social media in the West Papuan struggle, this was no online stunt. This was a petition

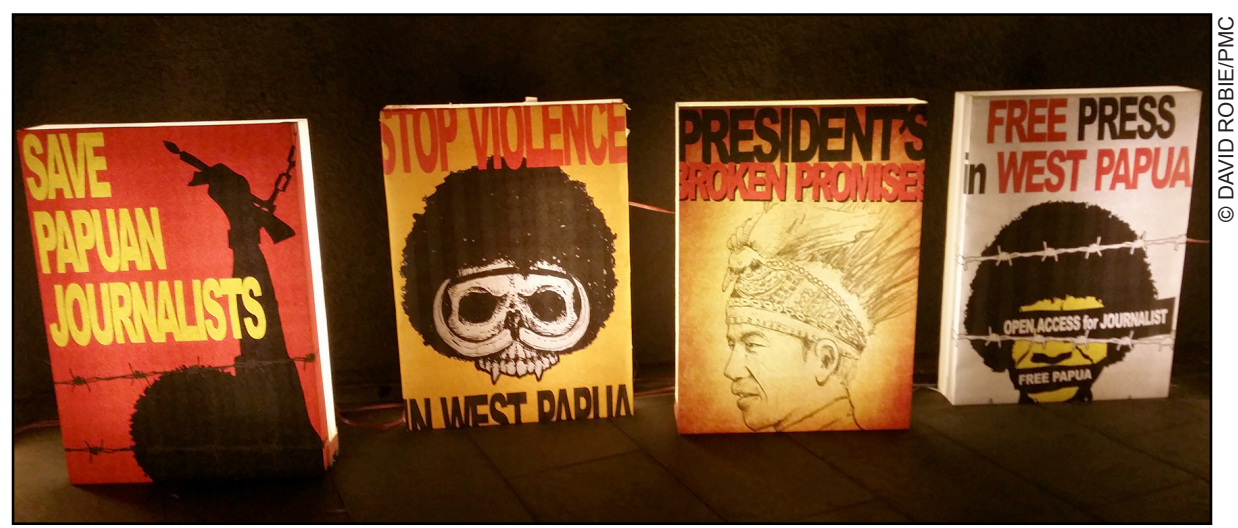

Figure 4: Papuan street art coinciding with the World Press Freedom Day conference in Jakarta, Indonesia, in May 2017. 
painstakingly collected by ULMWP organisers (p. 244) while travelling across the territory of West Papua at great risk of persecution and even death if caught by the security forces - they gathered 55,555 signatures along with names, addresses, signatures and even copied ID cards to prove their authenticity.

While in much of the rest of the world, petitions may be routine and taken for granted, in Indonesian-ruled West Papua it is different. Signing a petition like this, as MacLeod (p. 245) acknowledges, is tantamount to 'sedition'.

\section{Conclusion: The future and a challenge}

What does the future hold for West Papua? The optimism remains in spite of the great odds against self-determination. As the Reverend Dr Benny Giay wrote recently on the pages of Tabloid Jubi, a genuine resolution for West Papua will only come from Indonesia's willingness to listen and stop the oppression of West Papuans (Giay, 2016).

Meanwhile, environmental destruction and rampant militarism walk hand in hand in West Papua. Papuans are continuously stigmatised as backward, ignorant and poor. This has become a pretext for what Indonesian authorities call 'the acceleration and expansion of development'.

Pressed against waves of Indonesian migration, Papuans are not given any chance at all to develop themselves. They are a minority in their own land, not only in terms of number but also in terms of power. Every protest and negotiation effort by indigenous people is met with brutal responses and security operations.

This article is completed with a challenge to our foreign policy makers. I call on the Ministry of Foreign Affairs and Trade to recommend very strongly to the Republic of Indonesia that it must:

1. Conduct an impartial investigation into the cases of arbitrary arrest in West Papua, as well as other places in the Republic,

2. Guarantee the right to freedom of expression, and freedom of association and assembly for all Papuans,

3. Provide open access to West Papua for the international community, including journalists and NGO advocates,

4. Decide on a date as early as possible for the projected visit of the UN Special Rapporteur on Freedom of Expression and allow other mandate holders to visit West Papua, and

5. Press for a new independent UN 'self-determination' plebiscite for the future of West Papua. 


\section{References}

Abplanalp, K. (2015). Media restrictions on Papua-understanding the impacts. Unpublished Master of Communication Studies thesis and microsite, Pacific Media Centre, Auckland University of Technology.

Anonymous message to Indonesian government about West Papua genocide (2014, May 20). [Video] YouTube. Retrieved from www.youtube.com/watch? $\mathrm{v}=\mathrm{hOVKJRYQpAg}$ Blades, J. (2016). Watching this space, West Papua. Pacific Journalism Review, 22(1), 13-24. DOI: http://dx.doi.org/10.24135/pjr.v22i1.10

Blades, J. (2015, August 11). Jakarta cautiously lifts the veil in West Papua. Radio NZ Insight. Retrieved from www.radionz.co.nz/national/programmes/insight/audio/201777672/insight-for-8-november-2015-west-papua

Catholic Justice \& Peace Commission of the Archdiocese of Brisbane. (2016). 'We will lose everything': Report on a human rights fact finding mission to West Papua. Retrieved from https://cjpcbrisbane.files.wordpress.com/2016/05/we-will-loseeverything-may-2016.pdf

Coroner finds Balibo Five deliberately killed. (2007, November 15). Café Pacific. Retrieved from http://cafepacific.blogspot.co.nz/2007/11/coroner-finds-balibo-fivedeliberately.html

Cronau, P. (n.d.). Roger East 1922-1975, Journalist. ABC Memorial. Retrieved from www.abc.net.au/corp/memorial/rogereast.htm

Draunidalo issues public apology (2016, June 10). Fijilive. Retrieved from fijilive.com/ news/2016/06/draunidalo-issues-public-apology/62884.Fijilive

Elmslie, J. (2013). A slow-motion genocide: Indonesian rule in West Papua. Griffith Journal of Law \& Human Dignity, 1(2), 142-165.

Elmslie, J. (2017). Indonesia's West Papua: Settlers dominate coastal regions, highlands still overwhelmingly Papuan-West Papuan demographics revisited. The Asia Pacific Journal, 15(2), January 15. Retrieved from http://apjjf.org/-Jim-Elmslie/5005/article.pdf

Feagaimaali'i-Luamanu, J. (2017, September 7). Officials rubbish West Papua protest. Samoa Observer. Retrieved from www.samoaobserver.ws/en/08_09_2017/local/24074/ Officials-rubbish-West-Papua-protest.htm

Fiji MP Draunidalo suspended for rest of term. (2016, June 3). Radio New Zealand International. Retrieved from www.radionz.co.nz/international/pacific-news/305565/ fiji-mp-draunidalo-suspended-for-rest-of-term

Frain, S. C. (2016, March 3). Mariana Islands community groups to sue US Navy over at risk wildlife. Asia Pacific Report. Retrieved from http://asiapacificreport.nz/2016/03/03/ mariana-islands-community-groups-to-sue-us-navy-over-at-risk-wildlife/

Frain, S. C. (2017). Fanohge Famalåo'an \& Fan'tachu Fama'lauan: Women Rising Indigenous Resistance to Militarization in the Marianas Archipelago. Unpublished doctoral thesis, University of Otago. Retrieved from http://hdl.handle.net/10523/7486

Freedom House. (2015). Freedom of the press 2015-Indonesia. Retrieved from https:// freedomhouse.org/report/freedom-press/2015/indonesia

Front Rakyat Indonesia Untuk West Papua (Fri-West Papua). (2016, December 1). West Papua human rights violations 'worse' says new civil group. Asia Pacific Report. Retrieved from http://asiapacificreport.nz/2016/12/01/west-papua-human-rightsviolations-worse-says-new-civil-group/

Giay, Rev. B. (2016, May 6). Finding a dignified resolution for West Papua. Tabloid Jubi Online. Retrieved from tabloidjubi.com/eng/finding-a-dignified-resolution-for-west-papua/

Kabutaulaka, T. T. (2016, May 28). Don't be bullied, Indonesia is not Melanesia. Asia Pacific Report. Retrieved from http://asiapacificreport.nz/2016/05/28/tarcisius-tara- 
kabutaulaka-dont-be-bullied-indonesia-is-not-melanesia/

King, P. (2004). West Papua \& Indonesia since Suharto: Independence, autonomy or chaos. Sydney: University of New South Wales Press.

Koman, V. (2016, May 18). Papua: Pricking our national conscience. The Jakarta Post. Retrieved from www.thejakartapost.com/news/2016/05/18/papua-pricking-ournational-conscience.html

Lawyers Committee on Nuclear Policy Inc. (n.d.). The Marshall Islands nuclear zero cases in the International Court of Justice. Retrieved from http://cnp.org/RMI/

Leadbeater, M. (2006). Negligent neighbor: New Zealand's complicity in the invasion and occupation of Timor-Leste. Nelson: Craig Potton Publishing.

Leadbeater, M. (2018). Partners in crime: NZ's betrayal of West Papua. Dunedin, NZ: Otago University Press (forthcoming).

MacLeod, J.; Moiwend, R.; \& Pilborw, J. (2016). West Papua, human rights and Pacific diplomacy at the Pacific Island Forum and Melanesian Spearhead Group. Report for the United Liberation Movement for West Papua (ULMWP). Retrieved from www. ulmwp.org/wp-content/uploads/2016/09/WP_PIF_MSG_Report_Online_RLR-1.pdf MacLeod, J. (2015). Merdeka and the Morning Star: Civil resistance in West Papua. St Lucia, QLD: University of Queensland.

MacLeod, J. (2016). Citizen media and civil resistance in West Papua. Pacific Journalism Review, 22(1), 38-52.

Mariana Islands community groups to sue US Navy over at risk wildlife. (2016, March 3). Asia Pacific Report. Retrieved from asiapacificreport.nz/2016/03/03/marianaislands-community-groups-to-sue-us-navy-over-at-risk-wildlife/

Mass arrests reported in Indonesia's 'restive' Papua. (2016, May 4). Al Jazeera English. Retrieved from www.aljazeera.com/news/2016/05/mass-arrests-reported-indonesiarestive-papua-160503085332325.html

Matasororo, E. (2016). Standoff in Papua New Guinea: Students take issue over corruption. Pacific Journalism Review, 22(2), 13-19. doi: http://dx.doi.org/10.24135/pjr.v22i2.71

Motions-human rights, West Papua-media freedom. (2014, July 30). New Zealand Parliament. Parliamentary Business. Hansard excerpt. Retrieved from www.parliament. $\mathrm{nz} / \mathrm{en} / \mathrm{pb} / \mathrm{hansard}$-debates/rhr/document/50HansD_20140730_00000004/motionshuman-rights-west-papua-media-freedom

Nairn, A. (2010, November 9). Breaking news: Secret files show Kopassus, Indonesian Special Forces target Papuan churches, civilians. Documents leak from notorious US backed unit as Obama lands in Indonesia. Retrieved from www.allannairn.org/2010/11/ breaking-news-secret-files-show.html

Native Affairs - Inside West Papua (Parts 1 \& 2). (2015, September 28). Māori Television. Retrieved from www.maoritelevision.com/news/politics/native-affairs--inside-westpapua--part-1

Native Affairs sends first NZ TV crew to the [West Papua] region for 50 years. (2015, September 8). Pacific Media Watch 9419. Retrieved from www.pmc.aut.ac.nz/pacificmedia-watch/west-papua-native-affairs-sends-first-nz-tv-crew-region-50-years-9419

Perrottet, A., \& Robie, D. (2011). Pacific media freedom 2011: A status report. Pacific Journalism Review, 17(2), 147-186.

Reporters Sans Frontières (RSF). (2016a). 2016 World Press Freedom Index. Retrieved from https://rsf.org/en/indonesia

Reporters Sans Frontières (RSF). (2016b). RSF tells Indonesia to stop flouting journalists' rights in West Papua. Retrieved from https://rsf.org/en/news/rsf-tells-indonesia-stopflouting-journalists-rights-west-papua 
Robie, D. (1989). Blood on their banner: Nationalist struggles of the South Pacific. London: Zed Books.

Robie, D. (2013). Conflict reporting in the South Pacific: A critical reflexive approach to Timor-Leste and West Papua. Media Asia. 40(2), 147-161. doi: $10.1080 / 01296612.2013 .11689963$

Robie, D. (2014). Don't spoil my beautiful face: Media, mayhem and human rights in the Pacific. Auckland: Little Island Press.

Robie, D. (2015). Fiji, PNG lead betrayal, but still West Papuans triumph. [Media education blog]. Café Pacific: Media Freedom and Transparency. Retrieved from cafepacific.blogspot.co.nz/2015/06/fiji-png-lead-betrayal-but-still-west.html

Robie, D. (2016a, July). Editorial: Ruthless tidal wave. Pacific Journalism Review, 22(1), 6-12.

Robie, D. (2016b, July). Merdeka: Media and the case for Papuan civil resistance. Pacific Journalism Review, 22(1), 241-244.

Robie, D. (2016c, July 24). 'That day I saw the power of the media, and how it can be tragic.' Asia Pacific Report. Retrieved from asiapacificreport.nz/2016/07/24/davidrobie-that-day-i-saw-the-power-of-media-and-how-it-can-be-tragic/

Robie, D. (2017a, May 7). Rave hospitality, but Indonesia fails West Papua with media freedom hypocrisy. Asia Pacific Report. Retrieved from http://asiapacificreport. nz/2017/05/07/rave-hospitality-but-indonesia-fails-west-papua-with-media-freedomhypocrisy/

Robie, D. (2017b). Indonesian double standards over press freedom endanger safety of Papuan journalists. Media Asia, 44. (Forthcoming).

RSF tells Indonesia to stop flouting journalists' rights in West Papua. (2016, May 9). Reporters Without Borders. Retrieved on June 24, 2016, from rsf.org/en/news/rsftells-indonesia-stop-flouting-journalists-rights-west-papua

Sapiie, M. A. (2017, May 3). No talk of West Papua at Press Freedom Day. The Jakarta Post. Retrieved from www.thejakartapost.com/news/2017/05/03/no-talk-of-papuaat-press-freedom-day.html

Sauvakacolo, S. (2016, May 9). More Indonesian soldiers expected to rebuild QVS. The Fiji Times. Retrieved from www.fijitimes.com/story.aspx?id=353108

Shackleton, G. (1975). Archival Channel 7 footage from Balibó. [Video]. Retrieved from www.youtube.com/watch?v=ojS0B2WRS3o

Simons, M. (2016, October 5). Marshall Islands can't sue the world's nuclear powers, UN court rules. The New York Times. Retrieved from www.nytimes.com/2016/10/06/ world/asia/marshall-islands-un-court-nuclear-disarmament.html? $\mathrm{r}=0$

Somare condemns police for firing on UPNG students -8 wounded. (2016, June 8). Retrieved on June 26, 2016, from http://asiapacificreport.nz/2016/06/08/somarecondemns-police-for-firing-on-upng-students-deaths-reported/

Summary of Judgment of 5 October 2016-CIJ/ICJ. International Court of Justice. Retrieved from www.icj-cij.org/docket/files/158/19164.pdf

Swami, N. (2016, June 1). Reddy clears air on adopt a school program. The Fiji Times. Retrieved from www.fijitimes.com/story.aspx?id=356189

The Marshall Islands' Nuclear Zero cases in the International Court of Justice. (2016, April). Dramatic hearings. Retrieved from http://myemail.constantcontact.com/ LCNP-eNews--Dramatic-Hearings-in-The-Hague.html?

Titifanue, J., Tarai, J., Kant, R., \& Finau, G. (2017a). From social networking to activism: The role of social media in the free West Papua campaign. Pacific Studies Journal, 39(3), 255-280. Retrieved from https://papers.ssrn.com/sol3/papers.cfm?abstract_id=2935731 
Titifanue, J., Tarai, J., Kant, R., \& Finau, G. (2017b). Climate change advocacy in the Pacific: The role of information and communication technologies. Pacific Journalism Review, 23(1), 133-149. DOI: http://dx.doi.org/10.24135/pjr.v23i1.105

Webb-Gannon, C. (2015). Salvaging democracy for West Papuans in the face of AustraliaIndonesia obstruction, The Asia-Pacific Journal, 13(45:1). Retrieved from www. globalresearch.ca/salvaging-democracy-for-west-papuans-in-the-face-of-australiaindonesia-obstruction/5491606

Wenda, B. (2016a, June 16). Benny Wenda: Please hear my Papuan people's cry for freedom. Asia Pacific Report. Retrieved from asiapacificreport.nz/2016/06/16/bennywenda-please-hear-my-peoples-cry-for-freedom/

Wenda, B. (2016b, June 20). Indonesia attempts to crush mass peaceful rallies across West Papua. The Huffington Post. Retrieved from http://www.huffingtonpost.com/ benny-wenda/indonesia-attempts-to-cru_b_10515498.html

Wenda, B. (2016c, May 20). Getting the facts straight on West Papua. The Huffington Post. Retrieved from http://www.huffingtonpost.com/benny-wenda/indonesia-attempts-tocru_b_10515498.html

\section{Videos}

Balibó (2009). Director Robert Connolly [Feature film]. www.balibo.com

Blades, J. (2016, December 23). 'Everything can be burnt'-West Papua in the Jokowi era. [Video] Radio NZ International. Retrieved from https://www.youtube.com/ watch? $\mathrm{v}=\mathrm{YbNNg} 3 \mathrm{rrtgo}$

Bring back West Papua to the Melanesian family. (2015, April 27). Produced by Papua Merdeka for the Melanesian Spearhead Group [Video]. Retrieved from https://www.youtube.com/watch? $=$ nS_DI5s5cv0

Davis, M. (2014, June 3). 'West Papua's new dawn', SBS Dateline. [Current affairs video]. Retrieved from www.youtube.com/watch?v= TRDJVwhQw8

Footprint Films Oz (2009, August 18). Balibó webisode 4: The death of the Balibó Five. [Video]. Retrieved from www.youtube.com $/$ watch? $\mathrm{v}=6 \mathrm{jDhbfqs} 62 \mathrm{w}$

Kata, S. (2015). West Papua - behind the Native Affairs exclusive report. Pacific Media Centre. [Video]. Retrieved from https://www.youtube.com/watch? $\mathrm{v}=\mathrm{x}-\mathrm{MFCkfAVcQ}$ Papua Merdeka (2015, April 27). West Papua for Melanesian Spearhead Group [Video]. Retrieved from www.youtube.com/watch? $\mathrm{v}=\mathrm{nS} \_\mathrm{DI} 5 \mathrm{~s} 5 \mathrm{cv} 0$

Purdie, S. (2014, August 10). Media 'freedom' in West Papua exposed. Pacific Media Centre [Video]. Retrieved from www.youtube.com/watch?v=yvFSCJXsgqM

Dr David Robie is editor of Pacific Journalism Review, professor of Communication Studies and Pacific Journalism, and director of the Pacific Media Centre in the School of Communication Studies at Auckland University of Technology, Aotearoa/New Zealand. He is the author of several books on the political economy of Asia-Pacific media. An earlier version of this article was presented as a paper at the Otago University Foreign Policy School conference, 'Global Politics: From State to Social Media', University of Otago, Dunedin, 1-3 July 2016. david.robie@aut.ac.nz 